\title{
院内製剤レボチロキシンナトリウム注射液の定量と安定性*1
}

\author{
加藤裕久, 牉藤正明, 古泉秀夫, 豊田義雅 \\ 国立病院医镣センター薬骩科*2
}

\section{Determination and Stability of Levothyroxine Sodium Injections Prepared in Hospital*1}

\author{
YASUHISA KATO, MASAAKI SAITO, HIDEO KoIZUMI, \\ YoSHIMASA TOYODA \\ Department of Pharmacy, National Medical Center Hospital*2
}

(Received October 22, 1985)

\begin{abstract}
Levothyroxine sodium injections as hospital pharmacy products were prepared from L-thyroxine sodium and Thyradin-S tablet. An ion-pairing reversed-phase high-performance liquid chromatography was used for the determination of levothyoxine sodium. The recovery rates of levothyroxine sodium injections using $\mathrm{L}$-thyroxine sodium and dissolved by $0.1 \mathrm{~N} \mathrm{NaOH}$ were between 98.0 and $99.9 \%$, but those of products using Thyradin-S tablet were between 9.0 and $11.8 \%$.

Stability of levothyroxine sodium injection products was investigated in terms of their appearance and change of the content in 180 days.

As a result, significant change was observed in some conditions of preservations. Thus, levothyroxine sodium injection that was preserved at room temperature under UV light showed a low residual rate. However, it is considered that the levothyroxine sodium injections be useful if they are preserved in a dark, cold place.
\end{abstract}

Keywords_-levothyroxine sodium; L-thyoxine sodium; Thyradin-S tablet; high-performance liquid chromatography; ion-pairing reverse-phase; preservation; residual rate

\section{緒言}

甲状腺機能低下症や甲状腺手術後の患者への叶状腺木 ルモン剤の投与は，一般に経口的に行われている。 しか し，粘性水腫イレウスや粘性水腫昏睡等の症例では，意 識障害や消化管からの出血等により非経口损与が望ま れ, 実際に, 粘性水腫イレウス ${ }^{1,2)}$ や粘性水腫昏睡 ${ }^{3,4)}$ の 症例での甲状腺ホルモンの非経口投与が報告されてい る. そして，その適用の緊急性から注射剤での投与が最 良と思われる。

わが国では甲状腺ホルモン製剤の注射剤は製造，讯肘 されて抢らず，国外でもレボチロキシンナトリウム5 と トリヨードチロニン6) の注射剂が，各々 1 製剂ずつ製

*1 本報の一部は日病薬関東ブロック第 15 回学術大会 （新潟，1985年 8 月）にて発表.

*2 新宿区戸山 1 丁目21-1；21-1, Toyama 1-chome, Shinjuku-ku, Tokyo, 162 Japan
造，市肘されているのみで，入手は困難である。そこ で, 当院では幻覚妄想状態で発症したシーハン症候群の 患者に投与すべく, レボチロキシンナトリウム（以下 $\mathrm{T}_{4}$ - $\mathrm{Na}$ と略す）注射液を調製することとした．本剤は， シーハン症候群や粘性水腫昏睡等の症例で用いられ，緊 急を要するため, 用時調製されている. その安定性は確 認されていないが，調製後の長期保存が可能であれば， 緊急時の対応が容易となる.

今回, 逆相分配イオンペア高速液体クロマトグラフィ 一(以下 IP-HPLC と略す) を用いて, $\mathrm{T}_{4}-\mathrm{Na}$ の注射 液の定量及び安定性を検討したので報告する.

\section{実 験 方 法}

\section{1. 注射液の調製及び試薬}

$\mathrm{T}_{4}-\mathrm{Na}$ 注射液を, 試薬 $\mathrm{L}$-チロキシンナトリウム・5 水和物（Sigma）及び市肘チラージン®-S 錠を用い て, 無菌操作法により，5つの製剤処方 A, B, C, D 及 
び E を調製した。それらを Table 1 に示す。

処方 $\mathrm{A}$ は, 注射用蒸留水を用いて $0.1 \mathrm{~N}$ 水酸化ナトリ ウム溶液を調製し $121^{\circ} \mathrm{C}, 20$ 分高圧蒸気隇菌を行った. 次に $\mathrm{L}-$ チロキシンナトリウムを $0.1 \mathrm{~N}$ 水酸化ナトリウム 溶液 $0.5 \mathrm{ml}$ に溶解し, 注射用蒸留水を加えて全量 $100 \mathrm{ml}$ とした. メンブランフィルター $(0.22 \mu \mathrm{m})$ でろ過し, $2 \mathrm{ml}(100 \mu \mathrm{g} / \mathrm{ml})$ 宛, 隇菌バイアルに分注し製した. 処 方 Bは，L-チロキシンナトリウムを $0.1 \mathrm{~N}$ 水酸化ナトリ ウム溶液 $2.0 \mathrm{ml}$ で溶解した. 処方 C は， L-チロキシン ナトリウムを $0.1 \mathrm{~N}$ 水酸化ナトリウム溶液だけで溶解 し, 全量 $100 \mathrm{ml}$ とした. 処方 D は, 市販チラージン®-S 錠 $(50 \mu \mathrm{g} / \mathrm{T})$ を10錠とり, 粉砕して粉末状とした後, 注

Table 1. Levothyroxine $\mathrm{Na}$ Injections for Test

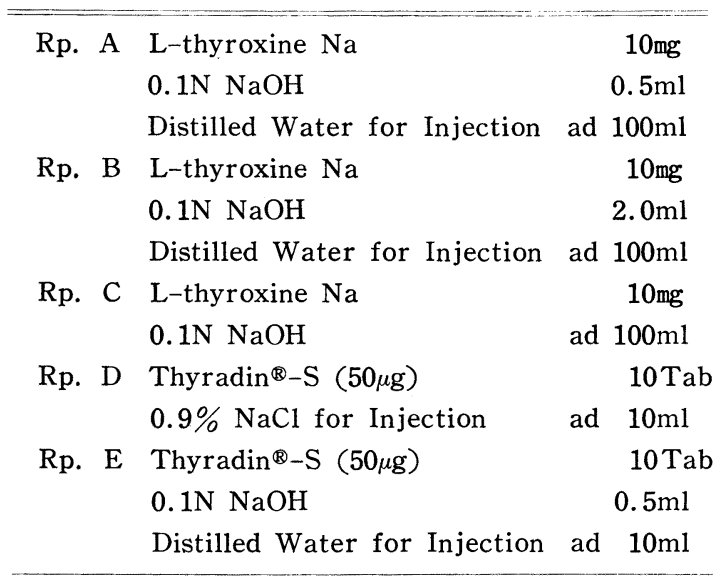

射用生理食塩液で溶解し, 全量 $10 \mathrm{ml}$ とした。これを入 ンブランフィルター $(3 \mu \mathrm{m})$ でろ過し, $2 \mathrm{ml}(50 \mu \mathrm{g} / \mathrm{ml})$ 宛, 隇菌バイアルに分注し製した。処括は, チラージ ン® $-\mathrm{S}$ 錠を前と同様，粉末状とした後，0.1N 水酸化ナ トリウム溶液 $0.5 \mathrm{ml}$ に溶解し, 注射用蒸留水で全量 $10 \mathrm{ml}$ とした. 処方 D と同様にろ過後, 分注し製した.

本定量法の内部標準物質は，3,5-ジョード-L-チロ = ン（Sigma）を用いた.メタノール，リン酸一カリウム 及び容量分析用 $2 \mathrm{~N}$ 水酸化ナトリウム溶液は, 和光純薬 工業製を用い，カウンターイオンとして1ーオクタンスル ホン酸 (Waters) を用いた. また他の試薬はすべて市販 特級規格品を用いた.

Table 2. Instrument and Instrumental Condition of Levothyroxine $\mathrm{Na}$

Liquid Chromatograph :

Shimadzu Model LC-3A with UV detector

Column : Zorbax-ODS $(4.6 \mathrm{~mm} \times 250 \mathrm{~mm})$

Column Temperature : Ambient

Eluate : $0.1 \mathrm{M} \mathrm{KH} \mathrm{KH}_{2} \mathrm{PO}_{4}$ : Methanol $(2: 3)+\mathrm{PIC}$ $\mathrm{B}-\mathbf{8}^{*}$

Flow rate $: 0.9 \mathrm{ml} / \mathrm{min}$

Pressure : $140 \mathrm{~kg} / \mathrm{cm}^{2}$

Detector : UV $254 \mathrm{~nm}$

Sensitivity : 0.02 AUFS

Extractant : 3,5-diiodo-L-thyronine (Sigma)

* 0.005 M Octane sulfonic acid

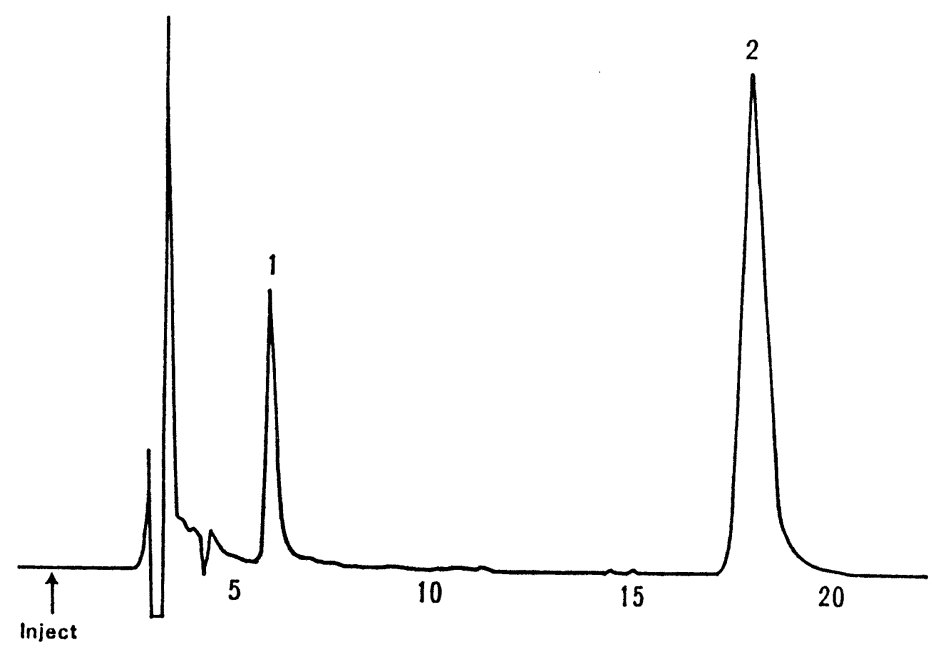

Fig. 1. High Performance Liquid Chromatogram

$1: 3,5$-diiode-L-thyronine (Internal Standard)

$2:$ Levothyroxine $\mathrm{Na}$ 


\section{IP-HPLC の測定条件}

$\mathrm{T}_{4}$-Na の IP-HPLC 法による測定条件を Table 2 飞 示す. カラムは Zorbax-ODS, 移動相には $0.1 \mathrm{M}$ リン 酸二水素カリウム : メタノール $(2: 3)$ 飞 $0.005 \mathrm{M}$ オク タンスルホン酸を加党, 内部標準物質として3,5-ジョー ド-L-チロニンを用いて, 検出波長 $254 \mathrm{~nm}$ で測定した.

\section{3. $\mathrm{T}_{4}-\mathrm{Na}$ の定量法}

$\mathrm{T}_{4}-\mathrm{Na}$ を分離したクロマトグラムを Fig. 1 亿示す. $\mathrm{T}_{4}-\mathrm{Na}$ と3, 5-ジョード-L-チロニン (I. S.) の保持時間 は18.3min と $5.8 \mathrm{~min}$ であり, 完全に分離した。

各注射液 $1.0 \mathrm{ml}$ に $0.1 \mathrm{~N}$ 水酸化ナトリウム溶液 $4.0 \mathrm{ml}$ を加え, 試験溶液とした。

$\mathrm{L}$ 一チロキシンナトリウムを $0.1 \mathrm{~N}$ 水酸化ナトリウム溶 液で $10 \sim 120 \mu \mathrm{g} / \mathrm{ml}$ に調製し，標準溶液とした． $20 \mu \mathrm{l}$ カラムに注入して, 得られたクロマトグラムからピーク 高さ比を測定し, 検量線を作製した。

\section{4. 保存条件}

保存条件は, 室温・放置, 室温・しゃ光, 室温・U V 照射及び冷所・しゃ光の 4 条件で, 30 日までは10日毎, それ以後30日毎, 180 日間にわたり $\mathrm{T}_{4}-\mathrm{Na}$ の残存率を測 定した. 室温は $25 \pm 2^{\circ} \mathrm{C}$, 冷所は $5 \pm 2^{\circ} \mathrm{C}$ であった。 た，UV 照射は紫外線殺菌灯を用いた。保存条件を Table 3 亿示す.

Table 3. Preservation of Levothyroxine $\mathrm{Na}$ Injection

\begin{tabular}{ll}
\hline \multicolumn{1}{c}{ Temperature } & \multicolumn{1}{c}{ Light } \\
\hline Room Temp. & Non Shield \\
Room Temp. & Shield \\
Room Temp. & UV \\
Cool Place $\left(5 \pm 2^{\circ} \mathrm{C}\right)$ & Shield \\
\hline
\end{tabular}

Table 4. Recovery and Reproducibility of Levothyroxine $\mathrm{Na}$ Injection

\begin{tabular}{c|c|c|c}
\hline \hline Rp & Taken $(\mu \mathrm{g} / \mathrm{ml})$ & Found $(\mu \mathrm{g} / \mathrm{ml})^{*}$ & Recovery(\%) \\
\hline A & 100.0 & $98.0^{+} 2.1$ & 98.0 \\
B & 100.0 & $99.9_{-1.1}^{+}$ & 99.9 \\
C & 100.0 & $99.9^{ \pm} 1.3$ & 99.9 \\
D & 50.0 & $4.5_{4}^{+} 4.0$ & 9.0 \\
E & 50.0 & $5.9_{4}^{+} 4.3$ & 11.8 \\
\hline
\end{tabular}

※ mean \pm S.D. $\quad(n=5)$

\section{結果および考察}

\section{1. $\mathbf{T}_{4}-\mathrm{Na}$ の定量}

甲状腺ホルモンの HPLC 法による定量に秃いて，逆 相分配クロマトグラフィーを用いた方法は, 内外で報 告7)されているが，IP-HPLC を用いた方法は少ない。 カウンターイオンとして，0.005M オクタンスルホン酸 を用いた。

$\mathrm{T}_{4}-\mathrm{Na}$ の検量線は, Fig. 2 亿示すように $\mathrm{T}_{4}-\mathrm{Na}$ 濃度 と内部標準物質に対するピーク高さ比は, ほぼ原点を通 る良好な直線関係が得られた。

次に調製した各 $\mathrm{T}_{4}-\mathrm{Na}$ 注射液の回收率を Table 4 K 示す． L-チロキシンナトリウムを用いた処方 $\mathrm{A}, \mathrm{B}$ 及び Cの回収率は良好でほぼ100\%を示したが,チラージン® - $\mathrm{S}$ 錠を用いた処方 $\mathrm{D}$ 及び $\mathrm{E}$ の回収率は，9.0\%と $11.8 \%$ にすぎなかった．これは， $\mathrm{T}_{4}$ - $\mathrm{Na}$ が蒸留水には注とんど 溶解せず，水酸化ナトリウム試液に溶解するためで，ま た処方 Eで回収率が低いのは, 錠剤の賦形剤が多く, $\mathrm{T}_{4}-\mathrm{Na}$ が完全には溶解しきれないためと思われる。

\section{2. $\mathrm{T}_{4}-\mathrm{Na}$ の安定性}

回収率が良好であった処方 $\mathrm{A}, \mathrm{B}$ 及びCの各注射液の 180日間にわたる残存率の推移を Fig. 3，4 亿示す. 室 温・放置下での各注射液の残存率は, 処方Cを除いて, 180日後処方Aで $20.0 \%$, 処方Bで50.5\%まで低下した。 室温・しゃ光の条件では, 各注射液とも室温・放置下で の残存率よりもやや高く, 処方Aで43.0\%を示した. 室 温・UV 照射の条件では，残存率は著しく低下し，90日 後ですでに各注射液は 2.0 18.0\% まで低下し, 淡黄色 を呈した. この着色は $\mathrm{T}_{4}-\mathrm{Na}$ から遊離するョウ素による と思われる.8) 冷所・しゃ光の条件ではかなり安定で,

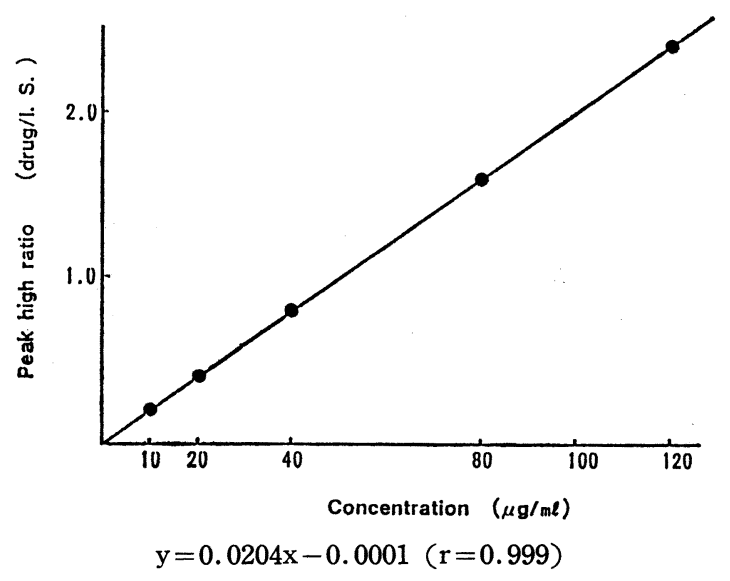

Fig. 2. Calibration Curve for Levothyroxine $\mathrm{Na}$ 

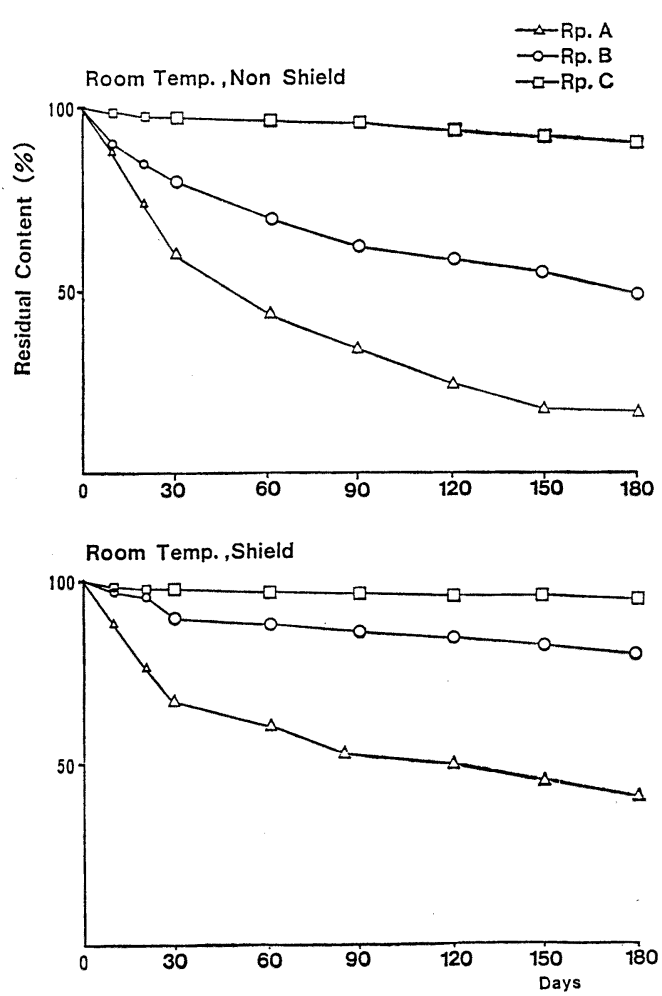

Fig. 3. The Residual Rate of Levothyroxine $\mathrm{Na}$ Injection

180日後でも処方Cで $99.5 \%$, 処方Aでも $61.0 \%$ を示し た.

$\mathrm{T}_{4}-\mathrm{Na}$ 注射液の安定性は, 宮内ら ${ }^{9)}$ がアンプルに封入 した場合「少なくとも 1 週間の保存期間では安定してい る」との報告のみで確認されてはいなかったが, 本実験 により, 試薬 L-チロキシンナトリウム・5 水和物を用 いて, $0.1 \mathrm{~N}$ 水酸化ナトリウム溶液で溶解, 調製し泠所・ しゃ光で保存すれば，少なくとも180日間あるいはそれ 以上安定であることが確かめられた.

\section{結 論}

$\mathrm{T}_{4}-\mathrm{Na}$ 注射液は, シーハン症候群や粘性水腫昏睡等の 症例で投与されるため緊急を要するが，その安定性は確 認されていなかった，しかし，本実験により，条件を設 定すれば少なくとも 180 日間あるいはとれ以上安定であ ることが判明した．ただし，処方 A 及び B は $\mathrm{pH}$ が約
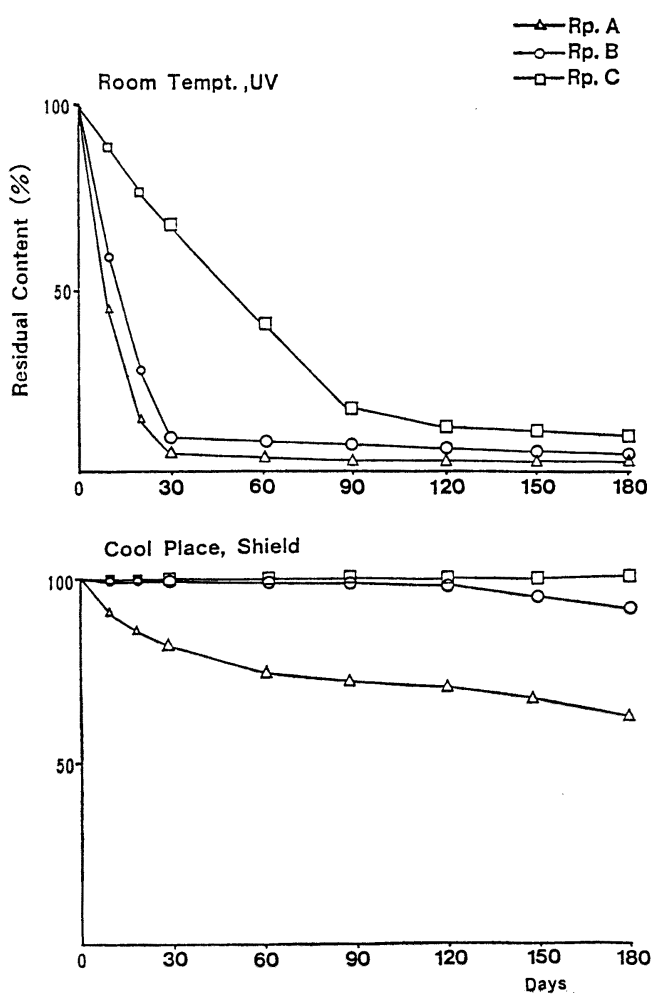

Fig. 4. The Residual Rate of Levothyroxine $\mathrm{Na}$ Injection

10, 処方Cでは約13とアルカリ性が強いため, その生理 作用を考慮して, 患者への投与は十分な注意が必要と思 われる。

\section{文献}

1) A. A. Abbasi et al. : J. A. M. A., 234, 181 (1975).

2) T. Batalis et al. : Br. J. Surg., 68, 439(1981).

3) M. Blum : Am. J. Med. Sci., 264, 433-443 (1972).

4) D. H. Holvey et al. : Arch. Inter. Med., 113, 139-146 (1964).

5) Extra Pharmacopoeia, 28, 1500 (1982).

6) P. D. R., 38, 953 (1984).

7) J. F. Brower et al. : Pharm. Sci., 73, a, 1315-1317 (1984).

8）西坦員男: “調剤学”, 南山堂, 東京, 1979, pp. 339-389.

9）宮内昭也：日内分泌会誌，60，23-29 (1984). 